\title{
Evaluation of available micro nutrients status of sandy loam soils of Gujba, Yobe State, Nigeria
}

\author{
Mulima, I. M. ${ }^{1}$, Ismaila, M. ${ }^{1 *}$, Daya, D. D. ${ }^{1}$, Talha, I. Z. ${ }^{2}$ and Abba Mani, F. ${ }^{2}$ \\ ${ }^{1}$ Department of Agricultural technology, Yobe State College of Agriculture Gujba, P. M. B. 1104, Damaturu, Yobe State, \\ Nigeria. \\ 2Department of Agricultural Technology, School of Agricultural Sciences and Technology, Ramat Polytechnic, P. M. B. \\ 1070, Maiduguri-Borno, Nigeria.
}

${ }^{*}$ Corresponding author. Email: ismimoh@gmail.com. Tel: 08060678580.

Copyright () 2018 Mulima et al. This article remains permanently open access under the terms of the Creative Commons Attribution License 4.0, which permits unrestricted use, distribution, and reproduction in any medium, provided the original work is properly cited.

Received 2nd July, 2018; Accepted 7th September, 2018

\begin{abstract}
A study was conducted in Gujba Local Government Area located in the southern part of Yobe state to evaluate the available micro nutrients status of sandy loam soils of Gujba. The drive towards self-sufficiency in food production through the adoption of more scientific intensive agricultural systems has necessitated the evaluation of the nutrient status of soils; most especially the micronutrients which had hitherto been neglected. Thus, thirteen locations were purposely selected to represent Gujba Local Government Area. In each location a total of 26 composite samples were collected using augers at two depth intervals of 0 to 15 and 15 to $30 \mathrm{~cm}$. At each depth, 5 samples were collected and composited. Standard laboratory procedures were followed to determine the physio-chemical properties of the samples. Descriptive statistics (mean values) of soil parameters were computed and employed to compare the results with the relevant findings. Results obtained from this study indicate that the soils were generally sandy to loamy sand in texture, slightly acidic and low in organic carbon with low to medium contents of exchangeable bases and cation exchange capacity (CEC). Cu was found to be in the medium category while $\mathrm{Zn}$ was generally low. However, the soils contained Fe and $\mathrm{Mn}$ above the critical limits for crop production and categorized as "high". This might be a potential environmental problem as they may, upon complex reactions, result in the formation of plinthite- /- petroplinthite leading to hard pan formation; restricting rooting depth and causing infiltration and drainage problem in the soil. For sustainable arable crop production on the soils studied, there is therefore the need for application of organic matter to improve the overall fertility of the soil and to reduce the possible development of plinthic/petroplinthic layers and to formulate organo-mineral amendments that would enhance in particular, $\mathrm{Zn}$ availability.
\end{abstract}

Key words: Amendments, assessment, micronutrients, soil, sandy loam.

\section{INTRODUCTION}

The drive for targeting higher agricultural production needs a balanced use of nutrients which otherwise create problems of soil fertility exhaustion and nutrient imbalances not only of major but also of secondary and micronutrients (Patel and Singh, 2009). Whenever either of the nutrients is deficient, it resulted in abnormal growth, which sometimes cause complete crop failure. Most of micronutrients are associated with the enzymatic system of plants. Thus, micronutrient deficiency and toxicity can reduce plant yield (Tisdale et al., 1995). Besides, grain and flower formation does not take place in severe deficiency (Nazif et al., 2006). Through their involvement in various enzymes and other physiologically active molecules, these micronutrients are important for gene expression, biosynthesis of proteins, nucleic acids, growth substances, chlorophyll and secondary metabolites, metabolism of carbohydrates and lipids, stress tolerance and son on (Rangel, 2003; Gao et al., 2008).

Large hectares of arable land in Nigeria have been reported to be deficient in micronutrients and many of 
these deficiencies were brought about by the continuous use of inorganic fertilizers particularly nitrogen, phosphorus, and potassium by farmers. Limited use of organic manures as well as non-recycling of crop residues are some of the other factors contributing towards rapids exhaustion of micronutrients in soils. The drive towards self-sufficiency in food production through the adoption of more scientific intensive agricultural systems has necessitated the evaluation of the nutrient status of soils; most especially the micronutrients which had hitherto been neglected (Mustapha, 2003). Realizing the seriousness of the problems and considering the decreasing productivity, the present study was undertaken to evaluate the available micronutrients status of sandy loam soils of Gujba Local Government Area of Yobe State, Nigeria.

\section{MATERIALS AND METHODS}

\section{Site description}

The study was conducted in Gujba Local Government Area of Yobe state, Nigeria (Figure 1). Its headquarter is in the town of Buni Yadi at $11^{\circ} 16^{\prime} 08^{\prime \prime} \mathrm{N} 11^{\circ} 55^{\prime} 49^{\prime \prime} \mathrm{E}$ towards the south of the area; the eponymous town of Gujba lies in the north of the area. The total Area is $3,239 \mathrm{~km}^{2}$ (https://en.wikipedia.org/wiki/Gujba). The climate cndition in Yobe state is characterized by single long dry season followed by a shorter wet season. In the Sudan savanna, precipitation ranges from 800 to $1000 \mathrm{~mm}$. Mean annual temperature is $36^{\circ} \mathrm{C}$ increasing toward the Sahel zone to about $38^{\circ} \mathrm{C}$. Humidity is low throughout the dry season. Potential evapotranspiration exceed rainfall except for few months. The soils are grouped on the basis of parent materials into aeolian deposits, lacustrine, alluvial deposits, sedentary sandstone (Nwaka, 2012). Vegetation in the Sudan is dominated by scrubby vegetation interspaced with tall trees.

Thirteen locations were purposely selected to represent Gujba Local Government Area. These are: Buni Gari, College of Agriculture new site, Kasatchiya, Gujba Village, Kasatchiya Wango, College of Agriculture old site, Hore Yunwa, Katarko, Garin Shuwa, Buni Yadi, Garin Karekare, Cattle Ranch and Garin Itace.

\section{Sample collection}

In each location a total of 26 composite samples were collected using augers at two depth intervals of 0 to 15 and 15 to $30 \mathrm{~cm}$. At each depth, 5 samples were collected and composited. The samples were air dried, ground using porcelain pestle and mortar and passed through $2 \mathrm{~mm}$ mesh sieve.

\section{Sample analysis}

Particle size distribution was determined using hydrometer method as outlined by Anderson and Ingram (1993). Soil $\mathrm{pH}$ was determined potentiometric as described by Wendt (1996). Organic carbon was determined by Walkely-Black method as outlined by Anderson and Ingram (1993). Total $\mathrm{N}$ was determined by Modified Kjeldahl method as described by Anderson and Ingram (1989). Available P was determined using Mehlich-3 extraction procedures as described by Anderson and Ingram (1989). Exchangeable bases $(\mathrm{Ca}, \mathrm{Mg}, \mathrm{K}$ and $\mathrm{Na}$ ) were extracted with $1 \mathrm{~N}$ Ammonium acetate $\left(\mathrm{NH}_{4} \mathrm{OAC}\right)$ (Anderson and Ingram, 1993); $\mathrm{Ca}$ and $\mathrm{Mg}$ were determined using atomic absorption spectrophotometer while $\mathrm{K}$ and $\mathrm{Na}$ was determined using flame photometer. The extractable micro nutrients: $\mathrm{Zn}, \mathrm{Cu}, \mathrm{Fe}$ and $\mathrm{Mn}$ were extracted using $0.1 \mathrm{M}$ HCL solution (Osiname et al., 1973) and determined on an atomic absorption spectrophotometer (Model 210) at appropriate wave length.

\section{Statistical analysis}

Descriptive statistics (mean values) of soil parameters were computed and employed to compare the results with the relevant findings. Critical limits for interpreting levels of soil fertility parameters was adopted from Mustafa et al. (2011) and Adamu et al. (2014).

\section{RESULTS AND DISCUSSION}

\section{Particle size distribution of soil at the experimental site}

The particle size distributions of the soils are shown in Table 1 . The results indicated that the soils have relatively high sand with a mean value of $662 \mathrm{gkg}^{-1}$ and a mean clay content of $147 \mathrm{gkg}^{-1}$ giving the soils, a generally loamy sand to sand texture. This is expected and further ascertained by Jones and Wild (1975), who reported that most savanna soils are sandy in nature which is associated with low water holding capacity (WHC). This indicates that the soil would be prone to leaching due to the high presence of macro-pores of the dominating sand fraction. This could adversely affect the growth of crops because of probable low water and nutrient retention capacity which aid in high leaching of soil nutrients. The resulting clay content increases and subsequent sand fraction decreases with soil depth might be attributed to removal of the fraction by surface run-off and also by alluviation. This is a common phenomenon in soil in this agro-ecology as was also reported by Voncir et al. (2008).

\section{Soil reaction}

The soil reaction (in $\mathrm{H}_{2} 0$ ) ranged from $\mathrm{pH} 6.34$ to 6.54 (mean $=6.44$ ) indicating slightly acidic reaction (Table 2 ). Though generally acidic, the $\mathrm{pH}$ value varies between 


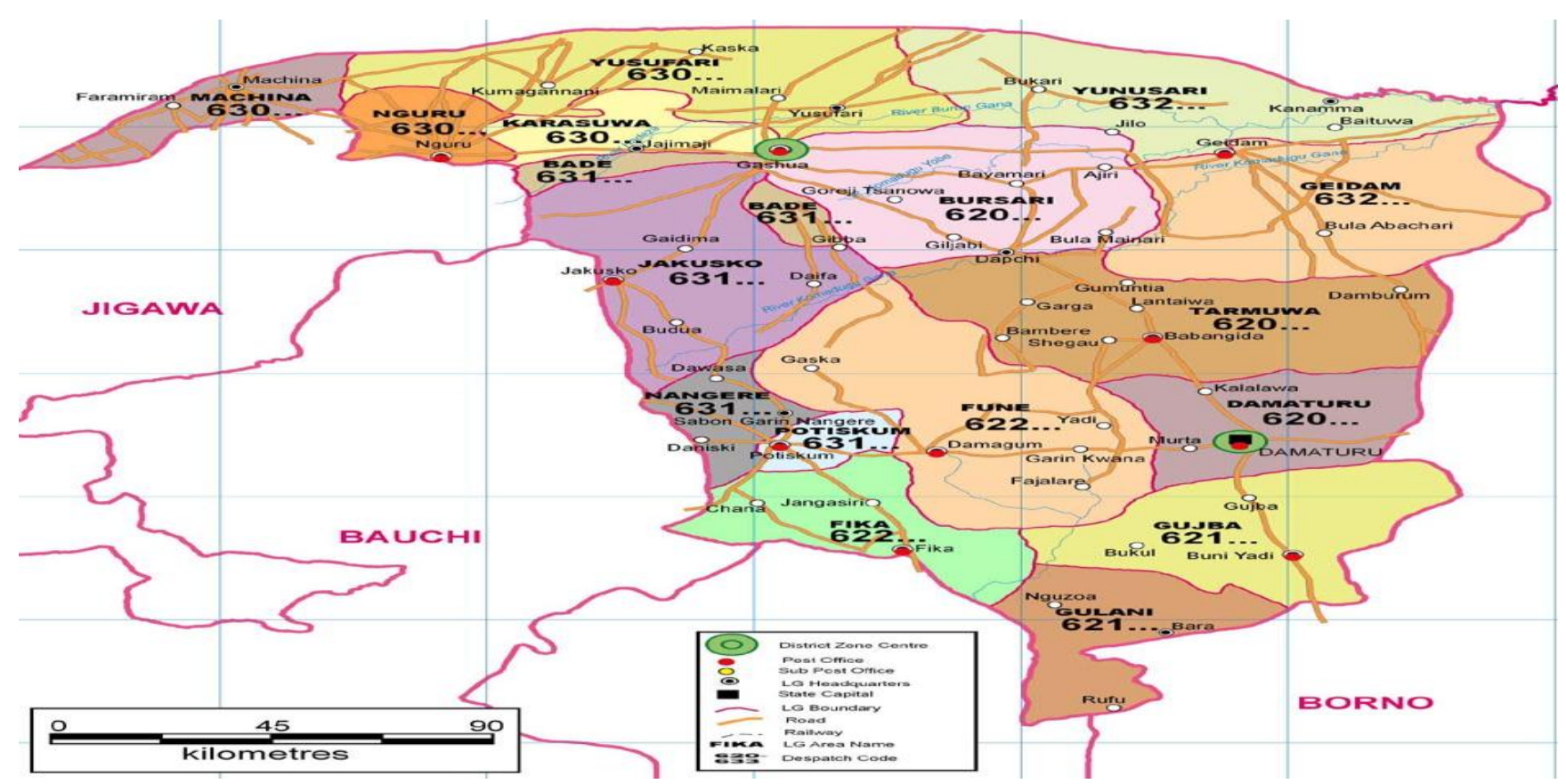

Figure 1. Map of Yobe State showing the local governments areas including the study locationsoil sampling and analysis.

Table 1. Particle Size distribution and Texture of some soils in Gujba LGA, Yobe State, Nigeria.

\begin{tabular}{|c|c|c|c|c|}
\hline Parameters & Sand $\left(g_{k g}{ }^{-1}\right)$ & Silt $\left(\mathrm{g} \mathrm{kg}^{-1}\right)$ & Clay $\left(\mathrm{g} \mathrm{kg}-{ }^{-1}\right)$ & Texture \\
\hline \multicolumn{5}{|l|}{ Location } \\
\hline Buni Gari & 540.24 & 230.28 & 220.48 & Sandy loam \\
\hline College of Agric N/site & 570.24 & 270.28 & 150.48 & Sandy loam \\
\hline Kasatchiya & 515.24 & 300.28 & 175.48 & Sandy loam \\
\hline Gujba Village & 505.24 & 285.28 & 195.48 & Sandy loam \\
\hline Kasatchiya Wango & 620.24 & 170.28 & 200.48 & Sandy loam \\
\hline College of Agric. Old site & 550.24 & 270.28 & 170.48 & Sandy loam \\
\hline Hore yunwa & 540.24 & 315.28 & 135.48 & Sandy loam \\
\hline Katarko & 530.24 & 340.28 & 120.48 & Sandy loam \\
\hline Garin Shuwa & 610.24 & 280.28 & 100.48 & Sandy loam \\
\hline Buni Yadi & 615.24 & 185.28 & 190.48 & Sandy loam \\
\hline Garin Karekare & 535.24 & 210.28 & 245.48 & Sandy loam \\
\hline Cattle Ranch & 622.24 & 228.28 & 149.48 & Sandy loam \\
\hline Garin Itace & 629.24 & 239.28 & 131.48 & Sandy loam \\
\hline Mean & 621.20 & 267.62 & 179.51 & \\
\hline $\mathrm{SE} \pm$ & 23.95 & 14.06 & 9.69 & \\
\hline \multicolumn{5}{|l|}{ Depth (cm) } \\
\hline $0-15$ & 533.47 & 231.51 & 156.48 & Loamy sand \\
\hline $15-30$ & 493.24 & 249.43 & 179.94 & Loamy sand \\
\hline Mean & 513.35 & 240.47 & 168.21 & \\
\hline SE \pm & 11.03 & 09.54 & 06.27 & \\
\hline
\end{tabular}

Source: Laboratory work.

depths considered. The surface $(0-15 \mathrm{~cm}) \mathrm{pH}$ was found to be more acidic than the subsurface $(15-30 \mathrm{~cm})$. This could be attributed to the removal of basic cation from the surface of the soil to the lower depths (Mustapha and 
Table 2. pH, O. C., T/N and Av-P distribution of some soils in Geidam LGA, Yobe State, Nigeria.

\begin{tabular}{|c|c|c|c|c|}
\hline Parameters & $\mathrm{pH}\left(\mathrm{H}_{2} \mathrm{O}\right)(1: 1)$ & O. C. $\left(\mathrm{g} \mathrm{kg}^{-1}\right)$ & T/Nitrogen $\left(\mathrm{g} \mathrm{kg}^{-1}\right)$ & Av-P $\left(\mathrm{mg} \mathrm{kg}^{-1}\right)$ \\
\hline \multicolumn{5}{|l|}{ Location } \\
\hline Bunu Gari & 5.86 & 5.09 & 0.48 & 7.26 \\
\hline College of Agric. New site & 6.16 & 5.54 & 0.49 & 7.68 \\
\hline Kasatchiya & 6.41 & 6.62 & 0.60 & 7.22 \\
\hline Gujba Village & 6.37 & 4.87 & 0.45 & 7.21 \\
\hline Kasatchiya Wango & 7.00 & 3.76 & 0.33 & 7.88 \\
\hline College of Agric. Old site & 6.54 & 5.33 & 0.43 & 7.27 \\
\hline Hore Yunwa & 6.14 & 5.53 & 0.55 & 8.18 \\
\hline Katarko & 6.79 & 6.08 & 0.57 & 7.18 \\
\hline Garin Shuwa & 6.12 & 7.57 & 0.56 & 6.68 \\
\hline Buni Yadi & 5.99 & 7.07 & 0.60 & 5.83 \\
\hline Garin Karekare & 5.97 & 6.52 & 0.54 & 7.02 \\
\hline Cattle Ranch & 6.15 & 9.89 & 0.83 & 12.63 \\
\hline Garin Itache & 7.02 & 6.59 & 0.71 & 9.00 \\
\hline Mean & 6.35 & 6.18 & 0.55 & 7.78 \\
\hline $\mathrm{SE} \pm$ & 0.08 & 0.01 & 0.08 & 0.42 \\
\hline \multicolumn{5}{|l|}{ Depth (cm) } \\
\hline $0-15$ & 6.54 & 7.26 & 0.64 & 8.20 \\
\hline $15-30$ & 6.15 & 5.11 & 0.46 & 7.26 \\
\hline Mean & 6.34 & 6.18 & 0.55 & 7.75 \\
\hline SE \pm & 0.41 & 1.08 & 0.16 & 1.40 \\
\hline
\end{tabular}

Source: Laboratory work.

Locks, 2005; Voncir et al., 2008; Kolo et al., 2009) and or the use of acid -forming fertilizer such as urea for agricultural purposes.

\section{Organic carbon}

Results (Table 2) show that the organic carbon content was within the "low" category (Esu, 1991) of fertility classes for Northern Nigeria Savanna soils. Difference was observed across surface $(0-15 \mathrm{~cm})$ and subsurface $(15-30$ $\mathrm{cm}$ ) with mean value of $4.82 \mathrm{gkg}^{-1}$ organic carbon content. This would suggest that the soils would be prone to leaching of nutrients. Similar low organic carbon values have been reported by Yaro et al. (2006) for the Nigeria savanna soils. Other reports indicated low organic carbon content for soils in the northern guinea savanna zone of Nigeria (Mustapha and Nnalee, 2007, Mustapha et al., 2007). The low organic carbon contents of the soils is characteristics of the savanna due to partly to rapid decomposition and mineralization of organic matter and to poor management sometimes by burning of crop residues by farmers (Lawal et al., 2012). Greenland (1995) attributed decline in soil organic matter content to intensification of agricultural activities through clearing and clean cultivation of soils for annual cropping. Thus, the farmers within the study area need to adopt cultural practices that will encourage the return and incorporation of plant/crop residues into the soils in order to improve the soil organic carbon level (Lawal et al., 2012).

\section{Total $\mathbf{N}$ and available $\mathbf{P}$}

The result has shown that the total Nitrogen across the locations and depths ranged from 0.33 to $0.83 \mathrm{gkg}^{-1}$ with a mean value of $0.58 \mathrm{gkg}^{-1}$ and 0.64 to $0.46 \mathrm{gkg}^{-1}$ with a mean value of $0.55 \mathrm{gkg}^{-1}$ respectively. These heralded a high amount of $\mathrm{N}$ (Esu, 1991). Available P contents in the soil ranged from 12.63 to $5.83 \mathrm{mgkg}^{-1}$ (mean $=9.23 \mathrm{mgkg}$ 1) across the locations and a mean value of $7.73 \mathrm{mgkg}^{-1}$ across the depths considered. These ranges was within the "low" fertility class (Enwezor et al., 1990, Esu, 1991).

\section{Exchangeable bases}

The exchangeable bases ( $\mathrm{Ca} \mathrm{Mg} \mathrm{K}$ and $\mathrm{Na}$ ) except $\mathrm{Na}$, significantly $(P<0.05)$ varied across depths (Table 3$)$. The exchangeable bases in this study are mostly rated low base on Esu (1991), critical limits and micro nutrients fertility ratings (Table 4 ). This reflects the low and medium CEC of the soils across the depth considered. This conforms to the findings of Oyinlola and Chude (2010). 
Table 3. Amount of Exchangeable Bases and CEC of some soils in Geidam LGA, Yobe State, Nigeria.

\begin{tabular}{|c|c|c|c|c|c|}
\hline Parameters & $\begin{array}{c}\mathrm{Ca} \\
\left(\mathrm{Cmol}(+) \mathrm{kg}^{-1}\right)\end{array}$ & $\begin{array}{c}\mathrm{Mg} \\
\left(\mathrm{Cmol}(+) \mathbf{k g}^{-1}\right)\end{array}$ & $\begin{array}{c}\mathrm{K} \\
\left(\mathrm{Cmol}(+) \mathbf{k g}^{-1}\right)\end{array}$ & $\begin{array}{c}\mathrm{Na} \\
\left(\mathrm{Cmol}(+) \mathrm{kg}^{-1}\right)\end{array}$ & $\begin{array}{c}\text { CEC } \\
\left(\mathrm{Cmol}^{(+)} \mathrm{kg}^{-1}\right)\end{array}$ \\
\hline \multicolumn{6}{|l|}{ Location } \\
\hline Buni Gari & 3.17 & 0.70 & 0.14 & 0.19 & 5.89 \\
\hline College of Agric $\mathrm{N} /$ site & 3.39 & 0.47 & 0.25 & 0.29 & 6.62 \\
\hline Kasatchiya & 3.53 & 0.73 & 0.19 & 0.18 & 6.18 \\
\hline Gujba Village & 3.34 & 0.73 & 0.20 & 0.16 & 5.70 \\
\hline Kachiya Wango & 4.62 & 0.51 & 0.22 & 0.16 & 8.52 \\
\hline College of Agric. Old site & 4.23 & 0.51 & 0.20 & 0.25 & 8.00 \\
\hline Hore Yunwa & 2.59 & 0.52 & 0.15 & 0.15 & 6.75 \\
\hline Katarko & 5.42 & 0.94 & 0.25 & 0.27 & 12.30 \\
\hline Garin Shuwa & 3.47 & 0.68 & 0.17 & 0.15 & 7.46 \\
\hline Buni Yadi & 2.73 & 0.66 & 0.18 & 0.19 & 6.10 \\
\hline Garin Karekare & 3.12 & 0.49 & 0.14 & 0.21 & 6.72 \\
\hline Cattle Ranch & 3.65 & 0.96 & 0.22 & 0.22 & 8.77 \\
\hline Garin Itace & 5.35 & 1.09 & 0.35 & 0.27 & 10.62 \\
\hline Mean & 3.47 & 0.69 & 0.20 & 0.20 & 7.66 \\
\hline SE \pm & 0.09 & 0.04 & 0.02 & 0.02 & 1.05 \\
\hline \multicolumn{6}{|l|}{ Depth (cm) } \\
\hline $0-15$ & 4.23 & 0.72 & 0.24 & 0.22 & 8.75 \\
\hline $15-30$ & 3.25 & 0.66 & 0.17 & 0.19 & 6.59 \\
\hline Mean & 3.74 & 0.69 & 0.20 & 0.22 & 2.60 \\
\hline SE \pm & 0.18 & 0.04 & 0.01 & 0.01 & 0.40 \\
\hline
\end{tabular}

Source: Laboratory work.

Table 4. Critical limits for interpreting levels of analytical parameters / Fertility rating.

\begin{tabular}{lccc}
\hline Parameter & Low & Medium & High \\
\hline $\left.\mathrm{Ca}^{2+}\left(\mathrm{cmol}_{+}\right) \mathrm{kg}^{-1}\right)$ & $<2$ & $2-5$ & $>5$ \\
$\left.\mathrm{Mg}^{2+}\left(\mathrm{cmol}_{+}\right) \mathrm{kg}^{-1}\right)$ & $<0.3$ & $0.3-1$ & $>1$ \\
$\mathrm{~K}^{+}\left(\mathrm{cmol}_{(+)} \mathrm{kg}^{-1}\right)$ & $<0.15$ & $0.15-0.3$ & $>0.3$ \\
$\mathrm{Na}{ }^{2+}\left(\mathrm{cmol}_{(+)} \mathrm{kg}^{-1}\right)$ & $<0.1$ & $0.1-0.3$ & $>0.3$ \\
Org. $\left(\mathrm{g} \mathrm{kg}^{-1}\right)$ & $<10$ & $10-15$ & $>15$ \\
Total N $\left(\mathrm{g} \mathrm{kg}^{-1}\right)$ & $<0.1$ & $0.1-0.2$ & $>0.2$ \\
Avail. P $\left(\mathrm{mg} \mathrm{kg}^{-1}\right)$ & $<10$ & $10-20$ & $>20$ \\
$\mathrm{Cu}\left(\mathrm{mg} \mathrm{kg}^{-1}\right)$ & $<0.2$ & $0.2-2.0$ & $>2$ \\
$\mathrm{Zn}\left(\mathrm{mg} \mathrm{kg}^{-1}\right)$ & $<0.8$ & $0.81-2.0$ & $>2$ \\
$\mathrm{Fe}\left(\mathrm{mg} \mathrm{kg}^{-1}\right)$ & $<0.2 .5$ & $0.2 .5-5.0$ & $>5$ \\
$\mathrm{Mn}\left(\mathrm{mg} \mathrm{kg}^{-1}\right)$ & $<1.0$ & $1.1-5.0$ & $>5$ \\
\hline
\end{tabular}

Adopted from Mustapha et al., (2011) and Adamu et al., (2014).

Source: Esu (1991).

\section{Cupper (Cu) status}

The contents of available $\mathrm{Cu}$ ranged from 1.33 to 0.77 $\mathrm{mgkg}^{-1}$ with a mean value of $1.09 \mathrm{mgkg}^{-1}$ in the studied zone (Table 5). Based on Esu (1991) micro nutrients fertility ratings (Table 4), the values is in the "medium" category. However these values are above the values reported by Mustapha and Singh (2003) for soils elsewhere in Galambi, Bauchi state, Nigeria in similar agro-ecology but similar to values obtained by Biwe (2012) in a study conducted in Gubi, Bauchi state, Nigeria. Between the depths considered, the upper surface $(0-15$ $\mathrm{cm})$ contained more $\mathrm{Cu}$ than the lower $(15-30 \mathrm{~cm})$ surface and both are within the "medium" fertility rating category 
Table 5. Distribution of Micronutrients in some soils of Geidam LGA, Yobe State, Nigeria.

\begin{tabular}{|c|c|c|c|c|}
\hline Parameters & $\mathrm{Cu}\left(\mathrm{mg} \mathrm{kg}^{-1}\right)$ & $\mathrm{Zn}\left(\mathrm{mg} \mathrm{kg}^{-1}\right)$ & $\mathrm{Fe}\left(\mathrm{mg} \mathrm{kg}^{-1}\right)$ & $\operatorname{Mn}\left(\mathrm{mg} \mathrm{kg}^{-1}\right)$ \\
\hline \multicolumn{5}{|l|}{ Location } \\
\hline Buni Gari & 1.19 & 0.52 & 15.24 & 23.62 \\
\hline College of Agric. /Nsite & 1.22 & 0.41 & 13.56 & 16.98 \\
\hline Kasatchiya & 1.14 & 0.33 & 17.15 & 29.18 \\
\hline Gujba Village & 1.33 & 0.33 & 15.09 & 30.97 \\
\hline Kasatchiya Wango & 1.31 & 0.33 & 13.66 & 17.34 \\
\hline College of Agric./Osite & 0.95 & 0.53 & 17.38 & 21.34 \\
\hline Hore Yunwa & 0.77 & 0.63 & 13.74 & 29.09 \\
\hline Katarko & 1.12 & 0.67 & 11.69 & 21.05 \\
\hline Garin Shuwa & 1.01 & 0.49 & 19.45 & 23.97 \\
\hline Buni Yadi & 0.96 & 0.59 & 23.13 & 24.13 \\
\hline Garin karekare & 1.06 & 0.53 & 15.53 & 29.94 \\
\hline Cattle Ranch & 1.12 & 0.49 & 20.49 & 33.13 \\
\hline Garin Itache & 0.97 & 0.5 & 19.49 & 30.28 \\
\hline Mean & 1.08 & 0.48 & 16.05 & 25.28 \\
\hline SE \pm & 0.04 & 0.03 & 0.73 & 2.69 \\
\hline \multicolumn{5}{|l|}{ Depth $(\mathrm{cm})$} \\
\hline $0-15$ & $0.96 a$ & $0.58 b$ & $19.99 a$ & 31.19 \\
\hline $15-30$ & $1.22 \mathrm{a}$ & $0.06 b$ & $13.18 b$ & 19.27 \\
\hline Mean & 1.09 & 0.32 & 16.60 & 25.23 \\
\hline SE \pm & 0.66 & 0.19 & 7.01 & 3.02 \\
\hline
\end{tabular}

Source: Laboratory work.

(Esu, 1991). Thus, it could be predicted that the deficiency of $\mathrm{Cu}$ will not occur in these soils in the nearest future. Lombin (1983) had earlier reported that the contents of available $\mathrm{Cu}$ in soils of Northern Nigeria Savanna are adequate and poses no fertility problem.

\section{Zinc (Zn) status}

The contents of available $\mathrm{Zn}$ in the zone ranged from 0.67 to $0.33 \mathrm{mgkg}^{-1}$ with a mean value of $0.50 \mathrm{mg} \mathrm{kg}^{-1}$. Based on the critical limits of Esu (1991), all the soils are in the category of "low" Zn status and would require Zn fertilization for a better crop production except; few locations in the zone (table 5). The values obtained in the present study are indeed similar to $0.58 \mathrm{mgkg}^{-1}$ (mean) obtained by Mustapha et al. (2010) in a study carried out in Gombe, Nigeria. Zn distribution in surface $(0-15 \mathrm{~cm})$ was more than the $\mathrm{Zn}$ content in subsurface $(15-30 \mathrm{~cm})$, falling in to "low" fertility rating (Esu,1991) category. As Zn decreases with depths, its implication here is that plants may not have a Zn "store" in the lower surface $(15-30 \mathrm{~cm})$. Similar decrease with depth was also observed by Singh (1985) and Bassirani et al., (2011). This also conforms to the findings of Mustapha et al. (2011) in soils of Gombe, Nigeria.

\section{Iron (Fe) status}

This study reveals that the available Fe ranged from 23.13 to $11.69 \mathrm{mgkg}^{-1}$ with a mean of $16.60 \mathrm{mgkg}^{-1}$ and it is within the "High" category of Esu (1991) micronutrients fertility rating. These values are below the ones reported by Mustapha et al. (2010) for soils elsewhere in Gombe state (range $=18.40$ to $21.91 \mathrm{mgkg}^{-1}$; mean $=19.96 \mathrm{mg} \mathrm{kg}^{-1}$ ) but similar to Mustapha et al. (2011) for soils in Akko Local Government Area of Gombe State, Nigeria (range $=5.7$ to $14.9 \mathrm{mg} \mathrm{kg}^{-1}$; mean $=10.80 \mathrm{mg} \mathrm{kg}^{-1}$ ). Between the depths considered, Fe ranged from 19.99 to $13.18 \mathrm{mgkg}^{-1}$ in the zone. The high Fe contents in soil (above the critical limits of $2.5 \mathrm{mgkg}^{-1}$ crop production) means that the $\mathrm{Fe}$ deficiency is not likely for crops grown on these soils. This is especially so when viewed against the backdrop of reports (Mengel and Geurtzen, 1986) that Fe deficiency is very unlikely in acid soils; as it is known to be soluble under relatively acid and reducing conditions (Chestworth, 1991). However the presence of $\mathrm{Fe}$ in high concentrations in soils could lead to its precipitation and accumulation and upon complex chemical reactions lead to the formation of Plinthite (Laterite). This upon alternate wetting and drying could irreversibly form hard indurated material (Petroplintite or ironstone) which could restrict root penetration and drainage. This observation is similar to 
that of Mustapha et al. (2010).

\section{Manganese (Mn) status}

$\mathrm{Mn}$ in the studied soils ranged from 33.13 to $16.98 \mathrm{mg} \mathrm{kg}$ ${ }^{1}\left(\right.$ mean $\left.=25.46 \mathrm{mg} \mathrm{kg}^{-1}\right)$ and these values are rated "High" according to Esu (1991) fertility rating. This implies that the soils contain sufficient $\mathrm{Mn}$ for successful agriculture in the area studied as they are above the critical limits of 1 to 4 $\mathrm{mgkg}^{-1}$ (Sims and Johnson, 1991) and 1 to $5 \mathrm{mgkg}^{-1}$ (Esu, 1991). The values obtained are higher than the 7.89 to $12.00 \mathrm{mgkg}^{-1}$; means $=9.10 \mathrm{mgkg}^{-1}$ obtained by Mustapha (2003) for the Ustults in Bauchi state, Nigeria. The surface soil had more $\mathrm{Mn}\left(31.19 \mathrm{mgkg}^{-1}\right)$ content than the sub surface (19.27 $\left.\mathrm{mgkg}^{-1}\right)$. The high Mn content may not be unconnected to the acidic nature of the soils. These findings suggest that $\mathrm{Mn}$ content of the soils is high and cannot be a limiting factor to successful crop production in the area. Although, the high contents of $\mathrm{Fe}$ and $\mathrm{Mn}$ in the soils studied could lead to the formation of complexes which could lead to serious drainage and infiltration problems (Mustapha et al., 2011).

\section{Conclusion}

Results obtained from this study indicate that the soils were generally sandy to loamy sand in texture, slightly acidic and low in organic carbon with low to medium contents of exchangeable bases and CEC. Cu was found to be in the medium category while $\mathrm{Zn}$ was generally low in the zone. However, the soils contained $\mathrm{Fe}$ and $\mathrm{Mn}$ above the critical limits for crop production and categorized as "high". This might be a potential environmental problem as they may, upon complex reactions, result in the formation of plinthite-/-petroplinthite leading to hard pan formation; restricting rooting depth and causing infiltration and drainage problem in the soil. In view of the above observations, it is suggested that for sustainable arable crop production on the soils studied, there is therefore; the need for application of organic matter to improve the overall fertility of the soil and to reduce the possible development of plinthic/petroplinthic layers and to formulate organo-mineral amendments that would enhance in particular, $\mathrm{Zn}$ availability.

\section{CONFLICT OF INTEREST}

The authors declare that they have no conflict of interest.

\section{REFERENCES}

Adamu, G. K., Aliyu, A. K., \& Jabbi, A. M. (2014). Fertility Assessment of Soils under Rice Cultivation in Kadawa, Garun Mallam Local Government Kano State. Natural and Applied Sciences, 5(1), 2223-9553.
Anderson, J. M., \& Ingram, J. S. I. (1989). Tropical Soil Biology and Fertility: A handbook of methods of analysis. CAB International, Wallingford, UK. Pp. 45-55.

Anderson, J. M., \& Ingram, J. S. I. (1993). Colorimeter determination of ammonium. In: Tropical Soil Biology and Fertility: A Hand Book of Methods. CABI. pp. 73-79.

Bassirani, N. Abolhassani, M., \& Galavi, M. (2011). Distribution of Available Micronutrients as related to the soil characteristics of Hissar; Haryana (India). Africa Journal of Agricultural Research, 6(18), 4239-4242.

Biwe, E. R. (2012). Status and distribution of available micronutrients along a toposequence at Gubi Bauchi North Eastern Nigeria. International Research Journal of Agricultural Science and Soil Science, 2(10), 436-439.

Chestworth, N. (1991). Geochemistry of nutrients. In: Mortredt, J. J., Shuman, L. M., \& Welch, R. M. (eds). Micronutrients in Agriculture 2nd Edition. Soil Sci. Soc. Am. Inc. Madison; Wisconsin, U.S.A. Pp. 27-478.

Enwezor, W. O., Udo, E. J., Ayotade, K. A., Adepetu, J. A., \& Chude, V. O. (eds.) (1990). A review of soil and fertilizer use in Nigeria. In: FPDD. Literature review on soil fertility investigations in Nigeria (Five Volumes). Federal Ministry of Agriculture and Natural Resources, Lagos. 281 pp.

Esu, I. E. (1991). Detailed soil survey of NIHORT farm at Bunkure, Kano State, Nigeria. Institute of AgriculturalResearch, Zaria. p. 72.

Gao, S., Yan, R., Coa, M., Yang, W., Wang, S., \& Chen, F. (2008). Effect of $\mathrm{Cu}$ on growth, antioxidant enzymes and phenylalanine ammonialyase activities in Jatropha curcas L. Seedling Plant. Soil Environment, 54, 111-122.

Greenland, D. J. (1995). Long-term cropping experiments in developing countries: the need, the history, and future. In: J. C. Waterlow, D. G. Armstrong, L. Fowden and R. Riley (eds.). Feeding the world population of more than eight billion people: a challenge to science. Oxford University Press, Oxford, UK.

Jones, M. J., \& Wild, A. (1975). Soils of the West African Savanna Commonwealth Agriculture, Burcaux, Herpenden England. p. 246.

Kolo, J., Mustapha S., \& Voncir N. (2009). Profile distribution of some physic-chemical properties

Lawal, B. A., Odofin, A. J., Adeboye, M. K. A., \& Ezenwa, M. I. S. (2012). Evaluation of selected Fadama soils in Katcha local Government Area of Niger State for arable cropping. Nigerian Journal of Soil Science, (2), 22.

Lombin, G. (1983). Evaluating the micronutrients fertility of Nigeria's semi-arid savanna soils. I. Copper and manganese. Soil Science 135, 377-384.

Mengel, K., \& Geustren, G. (1986). Iron Chlororis and the cause of Chlorosis. Journal of Plant Nutrition, 9, 161-173.

Mustapha, S, Voncir, N, Abdullahamid, N. A. (2011). Status of some Available Micronutrients in the Haplicusters of Akko Local Government Area Gombe State Nigeria. International Journal of Soil Science, 6, 267-274.

Mustapha, S. (2003). Fertility status and productivity constraints of the basement complex-derived Ustults in Bauchi State, Nigeria. Journal of Agricultural Technology, 11, 11-19.

Mustapha, S., \& Loks, N. A. (2005). Distribution of available zinc, copper, iron and manganese in the fadama soils from two distinct agro-ecological zones in Bauchi State, Nigeria. Journal of Environmental Science, 9(2), 22-28.

Mustapha, S., \& Nnalee, C. C. (2007). Fertility and salinity / sodicity status of some fadama soils in Jos, Plateau State, Nigeria. Journal of Sustainable Development Agriculture and Environment, 3, 96-103. 
Mustapha, S., \& Singh, B. R (2003). Available Zinc, Copper Iron and Manganese Status of the basement complete rock derived lutisols in Bauchi state. A case study. Niger. Journal of Soil Research, 4, 3540.

Mustapha, S., Mamman, H. K., \& Abdulhamid, N. A. (2010) Status and distribution of extractable micronutrients in Haplustults in Yamaltu-Deba Local Government Area, Gombe state, Nigeria. Journal of Soil Science and Environmental Management. 1(8), 200-204

Mustapha, S., Yerima, S. I., Voncir, N., \& Ahmed, B. I. (2007). Contents and distribution of phosphorus forms in some haplic plinthaquults in bauchi local Government area, bauchi state, Nigeria. International Journal of Soil Science, 2, 197-203.

Nazif, W., Sajida, P., \& Saleem, I. (2006). Status of micronutrients in soils of Districts Bhimber (Azad Jammu and Kashmir). Journal of Agriculture and Biological Sciences, 1(2), 35-40.

Nwaka, G. I. C. (2012) Personal communication soils of Abuja. Lecture Notes on SOSS 21 Soil Survey and Classification. Communication Field Work on the Faculty Farm, University of Abuja.

of Haplustults in Gaba District, Central Nigeria. Journal of League Research Nigeria, 10, 71-77.

Osiname, O. A., Schulte E. E., \& Corey, R. B. (1973). Soil tests for available copper and zinc in soils of western Nigeria. Journal of the Science of Food and Agriculture, 24, 1341-1349.

Oyinlola, E. Y., \& Chude, V. O. (2010). Status of available micronutrients of the basement complex rock - derived Alfisols in northern Nigeria savanna. Tropical and subtropical Agroecosystems, 12, 229-237.

Rangel, Z. (2003). Heavy metals as essential nutrients. In: Prasad, M. N. V., Hagemeyer, J. (eds). Heavy metals stress in plants: Molecules to Ecosystems. Springer - Verlag Berlin, Heidelberg 271-294.
Patel, K. P., Singh, M. V. (2009). Scenario of micro - and secondary - nutrients deficiencies and their management in soils and crops of arid and semiarid regions of Gujarat. The Proceedings of the International Plant Nutrition Colloquium XVI, Department of Plant Sciences, UC Davis, UC Davis.

Sims, J. T., \& Johnson, G. V. (1991). Micronutrient soil test. In: Mortvedt, J. J., Cox, F. R., Shuman, L. M., \& Welch, R. M. (eds.), Micronutrients in Agriculture. (2nd ed.), Soil Science Society of America. Book series: 4 Madison, Wisconsin, USA.

Singh, K., \& Shukla, U. C. (1985). Response of wheat to Zinc application in different soils of Semi-Arid region. Journal of Indian Society of Soil Science, 33, 381-835.

Tisdale, S. L., Nelson, W. L., \& Beaton, J. D. (1985). Soil fertility and fertilizers. Collier Macmillan Publishers.

Voncir, N., Mustapha, S., Tenebe, V. A., Kumo A. L., \& Kushwaha, S. (2008). Content and profile distribution of extractable zinc $(\mathrm{Zn})$ and some physicochemical properties of soil along a toposequence at Bauchi, Northern Guinea Savanna of Nigeria. International Journal Soil Science, 3, 6268.

Wendt, J. W., (1996). Chemical Analysis Manual. Soil and Plant Samples. Rockefeller Foundation and Department of Agricultural Research and Technical Services, Lilongwe, Malawi.

Yaro, D. T., Kparmwang T., B. Raji A., \& Chude V. O. (2006). The extent and properties of phlinthite in a landscape at zaria, Nigeria. International Journal of Soil Science, 1, 171-183. 